\title{
Factors affecting the leadership effectiveness of hospital managers: A systematized review
}

\author{
Ali Sarabi Asiabar ${ }^{1}$, Abbas Saleh Ardestani*2 $^{* 2}$ \\ Received: 6 March 2017 \\ Published: 6 Feb 2018
}

\begin{abstract}
Background: Effective leadership is regarded as an important factor in organizational success. This study aimed at performing a systematic review on leadership effectiveness among hospital managers.

Methods: A search was conducted in ScienceDirect, ProQuest, Web of Science, Ovid, and Scopus databases on the factors related to effectiveness of hospital managers' leadership during 1990 and 2016. The initial results included 2795 papers, but after further investigation and qualitative evaluation using CASP-19, a total of 8 papers were included in the systematic review. Then, summarizing, classification, and comparison were used for data analysis and synthesis.

Results: From among the 8 investigated papers, 4 were conducted in different regions of the US and the other 4 studies were done in Canada, India, Turkey, and South Africa. The latest and oldest studies were conducted in 2016 and 1992, respectively. The papers included 4 reviews, 3 cross-sectional studies, and 1 qualitative study. Effective factors on the effectiveness of managers' leadership were identified and classified into 4 categories of self-management, people management, health services provision management, and nuclear management skills.

Conclusion: Despite the emphasis of various studies on the existence of different effective factors on hospital managers' leadership, all these factors can be categorized as people management skills, self-management skills, nuclear management skills, and health services provision skills.
\end{abstract}

Keywords: Leadership effectiveness, Self-management, Organizational success, Systematic review

Copyright $\odot$ Iran University of Medical Sciences

Cite this article as: Sarabi Asiabar A, Saleh Ardestani A. Factors affecting the leadership effectiveness of hospital managers: A systematic review. Med J Islam Repub Iran. 2018 (6 Feb);32:6. https://doi.org/10.14196/mjiri.32.6

\section{Introduction}

Effective leadership is considered as an important factor in organizational success (1-3). Generally, success in organizations is regarded as organizational effectiveness. Effectiveness is the extent to which an organization accomplishes its objectives. Nowadays, scholars believe that multiple criteria that evaluate various organizational duties according to different features should be considered to assess effectiveness $(3,4)$.

Studies show that the role of hospital managers is expanding day by day, and thus the assessment of their lead-

Corresponding author:Dr Abbas Saleh Ardestani, abb.saleh_ardestani@iauctb.ac.ir

1. PhD Candidate of Public Administration, Islamic Azad University, Tehran Central Branch, Faculty of Management, Tehran, Iran.

2. Faculty of Management, Islamic Azad University, Tehran Central Branch, Tehran, Iran. ership effectiveness in the field of health and treatment seems essential $(5,6)$. A review on the former studies shows that there is no evidence of investigating the extent and effectiveness of leadership in hospital management. Studies have revealed that organizational success depends on effective leadership and this applies to all organizations including universities (7). Effective leaders have the power and ability to guide the employees to achieve organizational objectives $(8,9)$. Moreover, effective leaders are those who are able to gather different individuals under a

$\uparrow$ What is "already known” in this topic:

The role of hospital managers is expanding day by day, and thus assessing their leadership effectiveness in the field of health and treatment seems essential.

$\rightarrow$ What this article adds:

Factors such as having interpersonal and external connection skills, sharing information, teamwork ability, motivating the employees, and the ability to make changes in the organization and solving problems are among the most important factors emphasized by different studies to demonstrate hospital managers' leadership effectiveness. 
unified theoretical and intellectual umbrella (7). Generally, effective leaders should have the following personality traits: self-confidence, responsibility, energy, innovation, the ability to solve interpersonal tensions, accept the consequences of their decisions, have temerity, and take the initiative in social situations (10).

In the literature of the past studies, there is little information on leadership effectiveness in the field of health and treatment (11). According to Bass et al. in 2009, weakness in selection and employment has resulted in lack of effective leaders in health and treatment organizations, especially hospitals (12).

Proposing an effective model for hospital managers' leadership effectiveness requires sufficient and simultaneous attention to both local and international information requirements. Designing and implementing a systematic review is one of the useful methods to access organized and comprehensive information on this subject (13). Systematic review of the previous studies means embarking on systematic identification of all available primary studies, critical evaluation of these studies, and synthesizing suitable studies' data, and in some cases, their quantitative analysis with a standard and systematic method, which is used to answer a question related to health (13). On the other hand, because hospital managers play a very important role in their organization's financial and managerial success, designing a proper national model to maximize their leadership effectiveness will help them reach this goal. Therefore, the present study aimed at conducting a systematic review on leadership effectiveness of hospital managers to extract the related and effective factors in this regard, which can be ultimately used to design a local model for hospital managers' leadership effectiveness in Iran.

\section{Methods}

\section{Type of study and method of data collection}

In this systematic review, research settings included cyberspace and libraries. Furthermore, research community included electronic paper sources of databases and papers of valid scientific journals, which have been specified separately according to searching strategy. The criterion for including the studies for the systematic review was as follows: including all the studies that have been conducted on leadership effectiveness of hospital managers during the last 26 years, from 1990 until 2016. The exclusion criteria were as follow: studies whose original paper has been published in a language other than English, those studies whose original paper was not available at all, and those that were not directly related to this study's subject. The main goal of this systematic review was to find the factors related to leadership effectiveness of hospital managers around the world.

\section{Searching strategies}

The required data were collected from Scopus, Ovid, Web of Sciences, ProQuest, and ScienceDirect databases using the following key terms: "Manage", "Hospital", "Effective", and "Leadership". To find more published articles, some valid journals were used after searching the databases. After omitting some articles that were weakly related to the goals of the study and choosing the main articles, the reference lists of the articles were checked once again to ensure identification reliability.

\section{Screening}

In the primary search, 2795 studies were obtained from 5 valid databases (1653 from Scopus, 540 from Ovid, 3 from Web of Sciences, 499 from ProQuest, and 100 from

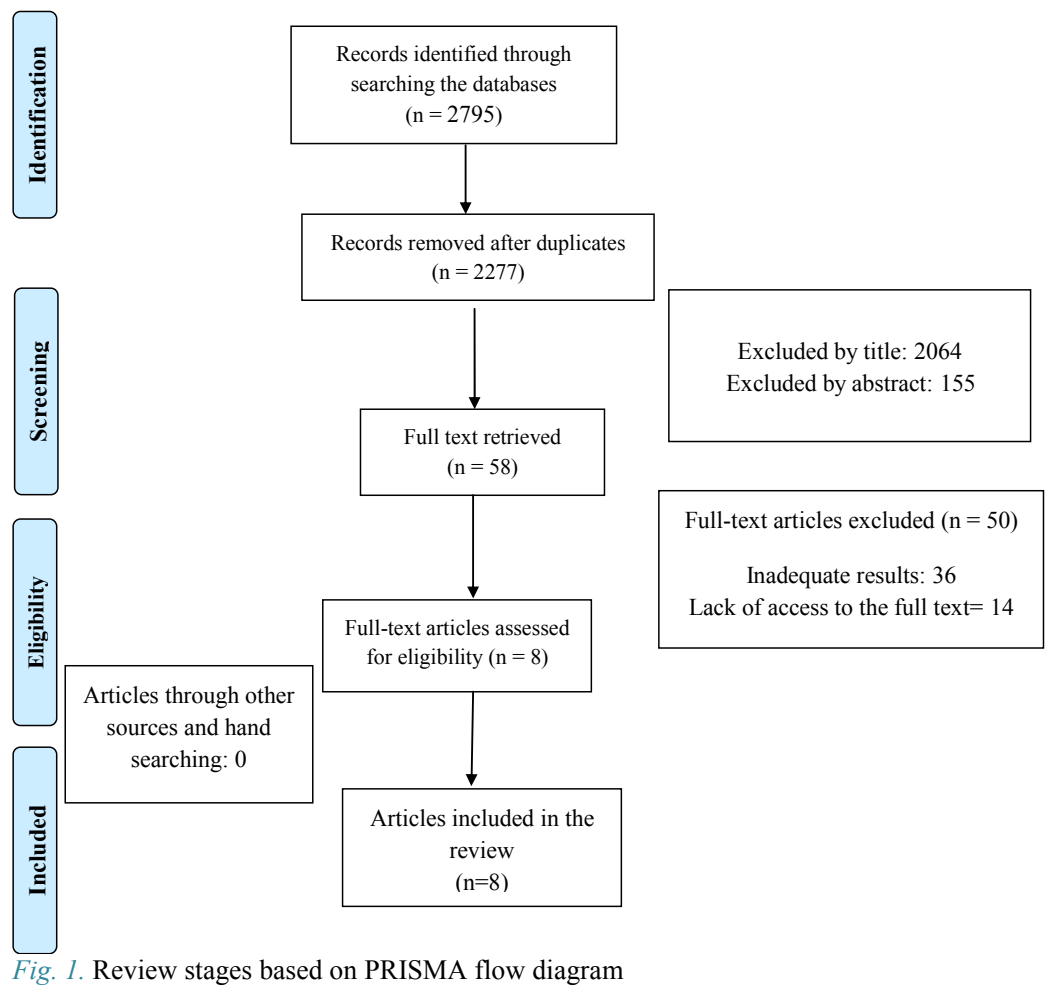




\begin{tabular}{|c|c|c|c|}
\hline & Title & Type of the study & Score \\
\hline 1 & Towards the development of professional management in Indian hospitals & Review & $65 \%$ \\
\hline 2 & Effective leadership: making the difference & Review & $62 \%$ \\
\hline 3 & Perceived managerial and leadership effectiveness within Turkish public sector hospitals & Cross-sectional & $85 \%$ \\
\hline 4 & $\begin{array}{l}\text { "What you see depends on where you stand": exploring the relationship between leadership behaviour and } \\
\text { job type in health care }\end{array}$ & Qualitative & $75 \%$ \\
\hline 5 & Leadership behavior and employee effectiveness & Cross-sectional & $82 \%$ \\
\hline 6 & Challenges of leadership in health care reform & Review & $70 \%$ \\
\hline 7 & Health care leadership in the public interest & Review & $65 \%$ \\
\hline 8 & The skills gap in hospital management in the South African public health sector & Cross-sectional & $90 \%$ \\
\hline
\end{tabular}

ScienceDirect). After identifying the repeated cases using ENDNOTE software, the number of studies was reduced to 2277. Moreover, 2064 papers and 155 papers were omitted after investigating their titles and abstracts, respectively, 36 papers were omitted due to incomplete data, and 14 papers were also excluded because access their complete text was impossible. Finally, the remaining 8 papers obtained the required credit to undergo qualitative assessment by CASP tool and were ultimately used in the systematic review (Fig. 1). Moreover, some techniques such as summarization, classification, and comparison were utilized for data analysis and synthesis.

\section{Results}

A total of 8 papers were finally used in this systematic review (Table 1). Of them, 4 were conducted in different regions of the US and the other 4 were conducted in Canada, India, Turkey, and South Africa. The latest and the oldest studies were published in 2016 and 1992, respectively. Moreover 4 of these studies were reviews, 3 were cross-sectional, and 1 was qualitative. No systematic review was found on the subject of this study. Hence, it can be claimed that this study was the first systematic review on the leadership effectiveness of hospital managers. Due to the heterogeneity of the studies and lack of sufficient literature on leadership effectiveness of hospital managers, performing a meta-analysis was not feasible in this study. Features of these studies and a summary of their results that demonstrated the effective and related factors in leadership effectiveness of hospital managers are presented in

Table 2. Characteristics and summary of findings of the included studies

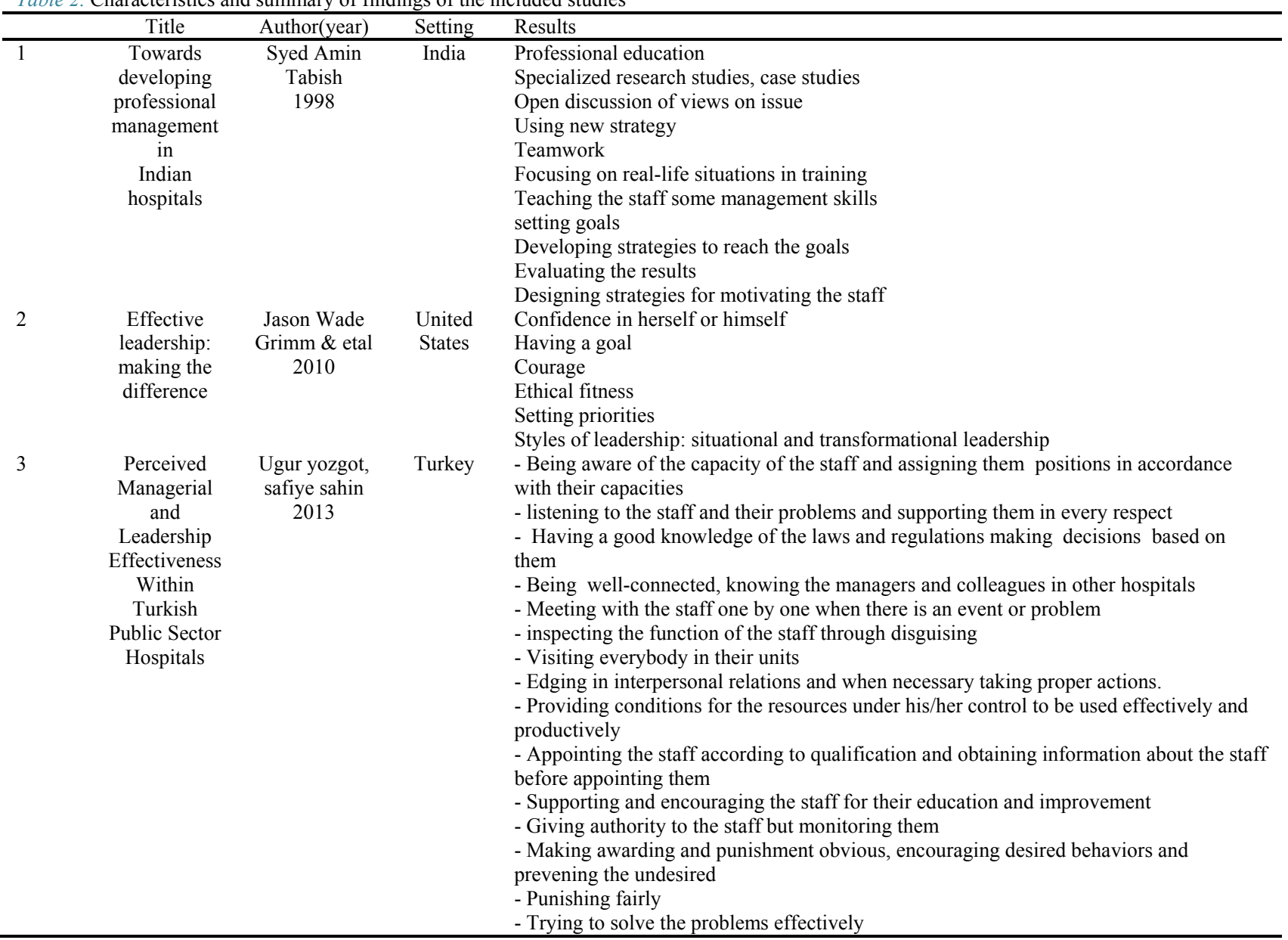




\begin{tabular}{|c|c|c|c|c|}
\hline 3 & $\begin{array}{l}\text { Perceived Managerial } \\
\text { and Leadership } \\
\text { Effectiveness } \\
\text { Within Turkish Public } \\
\text { Sector Hospitals }\end{array}$ & $\begin{array}{c}\text { Ugur } \\
\text { yozgot, } \\
\text { safiye sahin } \\
2013\end{array}$ & Turkey & $\begin{array}{l}\text { - using the concept of participative management } \\
\text {-Supporting teamwork } \\
\text { - Using technical information and skills } \\
\text { - Creating a positive atmosphere }\end{array}$ \\
\hline 4 & $\begin{array}{l}\text { "What you see depends } \\
\text { on } \\
\text { where you stand", } \\
\text { exploring } \\
\text { the relationship between } \\
\text { leadership behavior and } \\
\text { job } \\
\text { type in health care }\end{array}$ & $\begin{array}{c}\text { Laura } \\
\text { Gover and } \\
\text { Linda } \\
\text { Duxbury } \\
r .17\end{array}$ & Canada & $\begin{array}{l}\text { Good communication skills } \\
\text { Being encouraging and supportive } \\
\text { Friendly behavier } \\
\text { Recognizing others' contributions } \\
\text { Thinking of the bigger picture and impacting others } \\
\text { Being familiar with the organization } \\
\text { Making changes } \\
\text { Being consultative } \\
\text { Being professional } \\
\text { Paying attention to patients' needs }\end{array}$ \\
\hline 5 & $\begin{array}{l}\text { Leadership behavior and } \\
\text { employee effectiveness }\end{array}$ & $\begin{array}{l}\text { McNeese- } \\
\text { Smith, } \\
\text { Donna } \\
\text { (1993) }\end{array}$ & $\begin{array}{l}\text { United } \\
\text { States }\end{array}$ & $\begin{array}{l}\text { In each of the leadership practices (challenging the process, inspiring a shared } \\
\text { vision, enabling others to act, modeling the way, encouraging the heart), there was } \\
\text { a statistically significant positive correlation between the managers' scores as rated } \\
\text { by their employees and the employees' scores on the productivity, job satisfaction, } \\
\text { and organizational commitment scales. } \\
\text { Those who work in hospitals are more inclined to commit to an organization if } \\
\text { their manager challenges the job, questions the status quo, handles stress well, and } \\
\text { takes risks. }\end{array}$ \\
\hline 6 & $\begin{array}{l}\text { Challenges of leadership } \\
\text { in an era of health care } \\
\text { reform }\end{array}$ & $\begin{array}{l}\text { Chapman, } \\
\text { Thomas } \\
\text { W(1993) }\end{array}$ & $\begin{array}{l}\text { United } \\
\text { states }\end{array}$ & $\begin{array}{l}\text { Despite the challenges, those leaders who succeed in appealing to intrinsic } \\
\text { motivations will witness the benefits of a shared sense of vision and values. } \\
\text { Health care leader, perhaps more than ever, must know where the organization is } \\
\text { headed and issue a call to others to help guide it toward its destination. } \\
\text { Successful chief executives will be those who recognize and nurture intangible } \\
\text { leadership qualities, including knowledge of self, commitment to service, and } \\
\text { depth and breadth of vision. }\end{array}$ \\
\hline 7 & $\begin{array}{l}\text { Health Care Leadership } \\
\text { in the Public Interest }\end{array}$ & $\begin{array}{l}\text { Vladeck, } \\
\text { Bruce C } \\
(1992)\end{array}$ & $\begin{array}{l}\text { United } \\
\text { States }\end{array}$ & $\begin{array}{l}\text { Effective leaders draw on the strengths of their organization's core activities and } \\
\text { build outward from them, but the necessary precondition is maintenance of that } \\
\text { core. } \\
\text { The successful health care leader will not only hear and seek to respond to the } \\
\text { community's health concerns but must also fulfill the obligation to tell the com- } \\
\text { munity what its health needs are. } \\
\text { Health care leaders must not only acknowledge the likelihood of change but also } \\
\text { help shape it. } \\
\text { The key to effective leadership in health care organizations is an effective two- } \\
\text { way communication with internal constituencies, the organization's communities, } \\
\text { and the broader public policy process. }\end{array}$ \\
\hline 8 & $\begin{array}{c}\text { The Skills Gap in } \\
\text { Hospital Management in } \\
\text { the } \\
\text { South African Public } \\
\text { Health Sector }\end{array}$ & $\begin{array}{l}\text { Rubin } \\
\text { Pillay } \\
2008\end{array}$ & $\begin{array}{l}\text { South } \\
\text { Africa }\end{array}$ & $\begin{array}{l}\text { People management skills (the ability to be a team player, to work with people } \\
\text { from different backgrounds, resolve conflicts, delegate tasks, and share } \\
\text { information) } \\
\text { Self-management skills (it is the ability to take responsibility for your life at work } \\
\text { and beyond.) } \\
\text { Task related skills or core management functions (finance, human resources, and } \\
\text { information technology) } \\
\text { Health delivery skills (clinical and public health skills important in health } \\
\text { management) }\end{array}$ \\
\hline
\end{tabular}

Table 2.

The main results of this study as a framework of the factors affecting the leadership effectiveness of hospital managers are presented in Fig. 2.

\section{Discussion}

This study was conducted in Iran to identify and categorize the effective factors in the leadership effectiveness of hospital managers to design a model to assess this important variable. A total of 8 studies were used in this systematic review, and the intended factors in each study were identified. Various factors affect leadership effectiveness of hospital managers. Pillay has classified these factors into 4 groups: the first group includes skills related to people management, such as the ability to work with people and team building, delegation, resolving organizational conflicts, and sharing information. Although it is believed that managers have a higher level of responsibility compared to other team members, they need to be open and communicative. Also, we need to bear in mind that having people management skills is important for both small and big organizations. The second group includes self-management skills, such as responsibility in personal life and work place, and studies have indicated that this skill is one of the most important skills in knowledge economy (14). Moreover, such skills help managers build their ladder of success and set goals and mange their time efficiently, so that they can avoid any personal and organizational stress. The third group includes nuclear management skills, such as financing, human resources management, and information technology. These are also the most important skills for managers regardless of the organizations in which they work. Hospital managers need to be aware of rules and regulations, so they can use them 


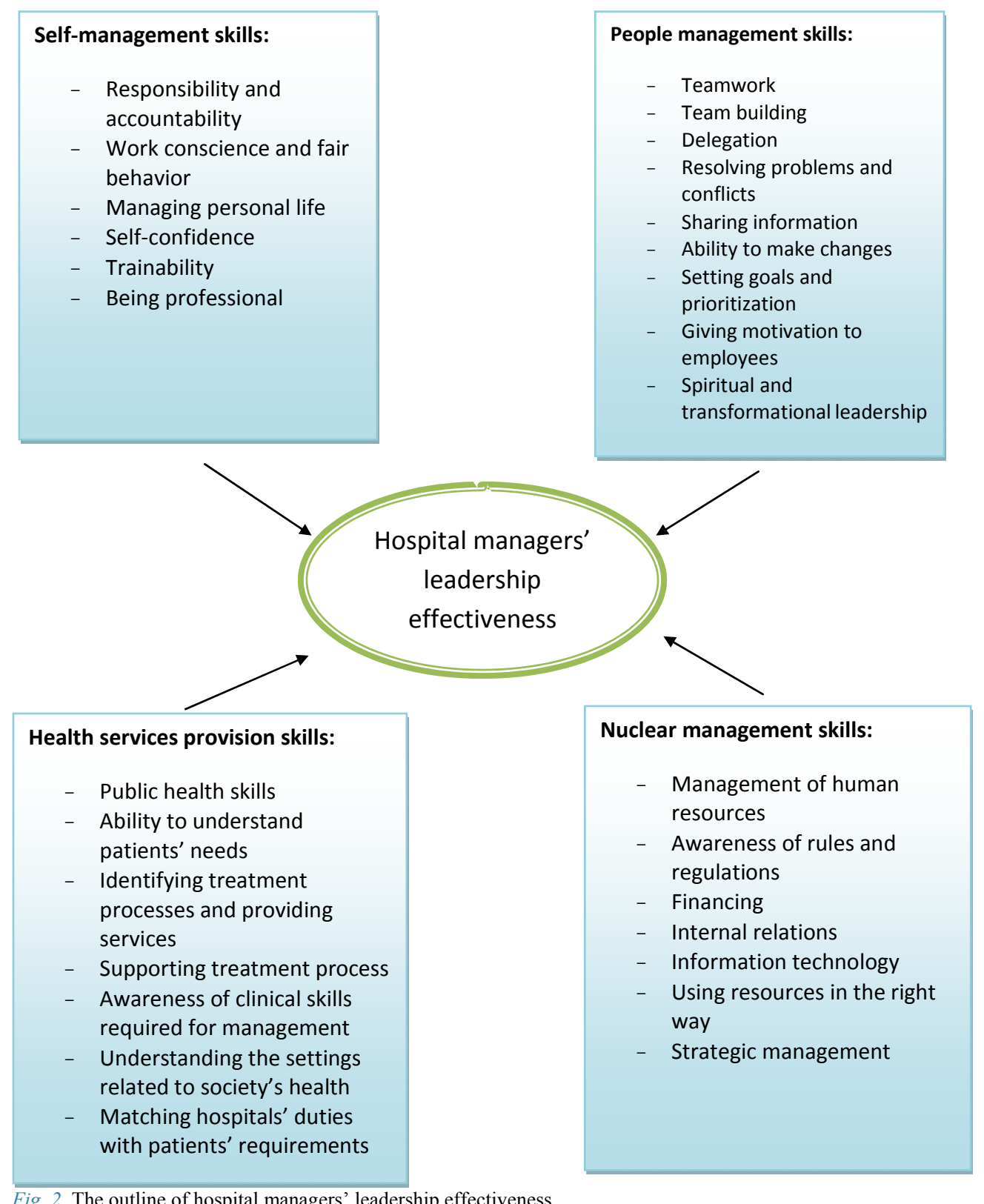

Fig. 2. The outline of hospital managers' leadership effectiveness

for appropriate management of human as well as financial resources.

Finally, the fourth group includes hospital managers' required skills for providing health services, such as general and clinical skills (14). Having some managerial skills, along with the ability to understand the clinical and general needs of patients, is what hospital managers really need. Having such skills differentiates hospital managers from other organizational managers. In a study conducted by Tabish, the effective factors in leadership ability of hospital managers were found to be research skills, setting goals, making use of strategies and teamwork, as well as right and fair assessment skills (15). Grimm et al. have considered setting and prioritizing goals, giving motivation to inferiors, spiritual leadership ability, and leadership commitment as the important factors influencing leadership effectiveness (16). Skills including motivating the staff, the ability to encourage employees for individual development, and contributing to organizational development have been emphasized in different studies carried out by Grimm et al., Sahin and Yozgot (2013), Gover and Dexbury (17) (2016), and Chapman (1993). It seems that the skills related to the ability to motivate the staff, and the ability to encourage them to reach organization's goals are among the most effective variables in leadership effectiveness model.

Other studies have also revealed a positive and significant relationship between leadership skills (understanding work procedures of the organization, drawing a perspective, the ability to employ other people effectively, being a role model, and having the ability to lead people's hearts) and managers' assessment score on their efficiency, job satisfaction, and organizational commitment given by their staff $(18,19)$. Literature shows that successful man- 
agers facilitate the staff's acceptance of the organization's perspectives and values by motivating them (20). In an extensive cross-sectional study in Turkey, Yozgot and Sahin provided a list of factors affecting hospital managers' leadership effectiveness. The most important factors on their list included the ability to identify the employees' capacities, the ability to listen to them and solve their problems, the ability to create a positive atmosphere, being aware of rules and regulations, making an external connection, especially with other hospitals' managers, using the resources effectively, and having good interpersonal and technical skills, and knowledge (21).

\section{Conclusion}

After reviewing the mentioned factors in different studies, it can be concluded that such factors as having interpersonal and external connection skills, sharing information, teamwork ability, motivating, and encouraging the employees, the ability to make changes in an organization, and solving problems are among the most important and repetitive factors emphasized by different studies to demonstrate hospital managers' leadership effectiveness. However, some other factors such as being aware of specific rules and regulations of hospitals and organizational structure, ability to manage the resources correctly, fair behavior, setting goals, and the ability to understand hospital settings correctly are among the important factors which cannot be ignored. It seems that the categorization presented by Pillay (2008) can be a good criterion for creating a classification and framework for various factors influencing the leadership effectiveness of hospital managers.

\section{Limitations}

The main limitation in this study was unavailability of the complete texts of some of the related studies. Revealing the effective factors can be the primary base for designing a local model to estimate the leadership effectiveness of hospital managers in Iran.

\section{Acknowledgements}

This study was part of a PhD thesis titled "Designing an assessment model for hospital managers' leadership effectiveness in Iran's medical and training hospitals", which was implemented with the support of Islamic Azad University.

\section{Conflict of Interests}

The authors declare that they have no competing interests. implementation of health sector evolution plan in Iran based on Pabon Lasso model. Iran J Public Health. 2017;46(3):389.

5. Macdonald I, Burke C, Stewart K. Systems leadership: Creating positive organisations: Taylor \& Francis; 2017.

6. Azar FE, Asiabar AS. Does leadership effectiveness correlates with leadership styles in healthcare executives of Iran University of Medical Sciences. Med J Islam Repub Iran. 2015;29:166.

7. Floros JD. Academic Leadership through Strategic Planning. Academic Leadership in Higher Education: From the Top Down and the Bottom Up. 2015:161.

8. Grohar-Murray ME, DiCroce HR, Langan JC. Leadership and management in nursing: Pearson; 2016.

9. Ardestani AS, Asiabar AS, Azar FE, Abtahi SA. The relationship between hospital managers' leadership style and effectiveness with passing managerial training courses. Med J Islam Repub Iran. 2016;30:465.

10. Thomas T. Management and leadership for nurse administrators: Jones \& Bartlett Publishers; 2015.

11. Bagheri R, Sohrabi Z. Psychometric properties of Persian version of the multifactor leadership questionnaire (MLQ). Med J Islam Repub Iran. 2015;29:256

12. Xu L, Wubbena Z, Stewart T. Measurement invariance of secondorder factor model of the Multifactor Leadership Questionnaire (MLQ) across K-12 principal gender. J Educ Administ. 2016;54(6):727-48.

13. Moher D, Shamseer L, Clarke M, Ghersi D, Liberati A, Petticrew $\mathrm{M}$, et al. Preferred reporting items for systematic review and metaanalysis protocols (PRISMA-P) 2015 statement. System Rev. 2015;4(1):1.

14. Pillay R. The skills gap in hospital management: a comparative analysis of hospital managers in the public and private sectors in South Africa. Health Serv Manage Res. 2010;23(1):30-6.

15. Chittoor RR, Aulakh PS. Organizational landscape in India: Historical development, multiplicity of forms and implications for practice and research. Long Range Plan. 2015;48(5):291-300.

16. Grimm JW. Effective leadership: making the difference. J Emerg Nurs. 2010;36(1):74-7.

17. Gover L, Duxbury L. "What you see depends on where you stand" exploring the relationship between leadership behavior and job type in health care. Leading in Health Care Organizations: Improving Safety, Satisfaction and Financial Performance: Emerald Group Publishing Limited; 2013. p. 35-65.

18. Van der Voet J. The effectiveness and specificity of change management in a public organization: Transformational leadership and a bureaucratic organizational structure. Europ Manag J. 2014;32(3):373-82.

19. Shanks NH. Introduction to health care management: Jones \& Bartlett Publishers; 2016.

20. Johnson CE. Meeting the ethical challenges of leadership: Casting light or shadow: Sage Publications; 2017.

21. Yozgat U, Şahin S. Perceived Managerial and Leadership Effectiveness within Turkish Public Sector Hospitals. Procedia Soc Behav Sci. 2013;99:216-21.

\section{References}

1. Conchie B. Strengths-based leaders. Leadership Excellence. 2009;26(2):10.

2. Ladegard G, Gjerde S. Leadership coaching, leader role-efficacy, and trust in subordinates. A mixed methods study assessing leadership coaching as a leadership development tool. Leaders Q. 2014;25(4):631-46

3. Thépot J. Leadership Styles and Organization: a Formal Analysis. Revue sciences de gestion. 2008;65:287-306.

4. Moradi G, Piroozi B, Safari H, Nasab NE, Bolbanabad AM, Yari A. Assessment of the efficiency of hospitals before and after the 